\title{
PERTANGGUNGJAWABAN PIDANA TERHADAP BIDAN YANG MEMBANTU MENANGANI ABORTUS PROVOCATUS SECARA ILEGAL
}

\author{
I Putu Wahyu Putra Suryawan, I Nyoman Gede Sugiartha, Diah Gayatri Sudibya \\ Fakultas Hukum Universitas Warmadewa, Denpasar-Bali, Indonesia \\ wahyuputras141@gmail.com, nyomansugiartha14@gmail.com, diahgayatridsudibya@gmail.com
}

\begin{abstract}
Abstrak
Abortus provokatus adalah hasil pengeluaran konsepsi sebelum waktunya kurang dari 20 minggu yang dilakukan secara sengaja dengan cara menggunakan obat atau alat-alat medis. Dewasa ini tindakan abortus provocatus marak dilakukan oleh remaja yang terlibat pergaulan bebas maupun wanita dewasa yang sudah menikah, dalam melakukan tindakan abortus provocatus ada yang dilakukan sendiri dengan menggunakan obat, ramuan tradisional atau pijatan, dan ada pula yang dibantu oleh tenaga kesehatan medis dokter dan bidan yang dilakukan secara ilegal. Penelitian ini bertujuan untuk mengetahui pengaturan hukum yang mengatur tentang perbuatan abortus provocatus secara legal, dan untuk mengetahui pertanggungjawaban pidana terhadap bidan yang membantu menangani abortus provocatus secara ilega. Penelitian ini menggunakan tipe penelitian hukum normatif, dengan mengkaji UUD NRI Tahun 1945, UU No 36 Tahun 2009 dan KUHP sebagai dasar untuk mengetahui pertanggungjawaban pidana terhadap bidan yang membantu menangani abortus provocatus secara ilegal. Hasil penelitian ini menunjukan bahwa pengaturan hukum mengenai tindakan aborsi provocatus secara legal diatur pada Pasal 75 ayat (2) UU Kesehatan, yang menyatakan bahwa larangan melakukan pengguguran dapat dicabut apabila dilakukan pada wanita hamil yang kandungannya mengalami gejala keadaan darurat medis yang membahayakan nyawanya / janin yang sedang dikandungnya mengidap penyakit-penyakit genetik atau cacat bawaan yang tidak memungkinkan untuk dapat disembuhkan sehingga berpotensi menyulitkan bayi untuk melangsungkan hidup secara normal. Kemudian, pertanggungjawaban pidana terhadap bidan yang membantu menangani abortus provocatus secara ilegal sanksinya berbeda dengan pertanggungjawaban pidana pelaku utamanya (dokter).
\end{abstract}

Kata Kunci: Abortus Provocatus; Ilegal; Pertanggungjawaban Pidana.

\begin{abstract}
Provocatal abortion is the result of expulsion of conception before its time less than 20 weeks which is done deliberately by using drugs or medical devices. Currently, provocatus abortion is rife with adolescents who are involved in promiscuity and adult women who are married. In carrying out the act of abortion provocatus, some are done by themselves using drugs, traditional ingredients or massage, and some are assisted by medical doctors and midwives. that is done illegally. This study aims to determine the legal arrangements governing the act of legally abortion provocatus, and to determine the criminal responsibility of midwives who help treat provocatus abortion legally. This research uses a type of normative legal research, by examining the 1945 Constitution of the Republic of Indonesia, Law No. 36 of 2009 and the Criminal Code as a basis for knowing criminal liability to midwives who help deal with illegal abortion provocatus. The results of this study indicate that the legal arrangements regarding provocatus abortion are legally regulated in Article 75 paragraph (2) of the Health Law, which states that the prohibition on abortion can be lifted if it is carried out on a pregnant woman whose womb experiences symptoms of a medical emergency that endangers her life / fetus being conceived is suffering from genetic diseases or congenital defects that do not allow it to be cured so that it has the potential to make it difficult for the baby to lead a normal life. Then, the criminal liability for a midwife who helps handle provocatus abortion illegally has different sanctions from the criminal responsibility of the main perpetrator (doctor).
\end{abstract}

Keywords: Provocatus Abortion; Illegal; Criminal Liability.

\section{PENDAHULUAN}

Ditinjau berdasarkan sudut pandang aturan hukum yang ada di Indonesia, dalam UUD NRI Tahun 1945, dalam pasal 28 I BAB XA diatur mengenai mengenai hak kehidupan setiap warga negara. Mengenai perampasan hak hidup setiap orang, termasuk mereka yang masih dalam kandungan, dapat dihukum dengan hukuman yang setimpal dengan perbuatannya sebagaimana diatur dalam Wetboek 
van Staatsrecht dan/atau kitab hukum pidana (Hamenda, 2013). Membahas masalah pengakhiran kehamilan secara sengaja atau yang biasa disebut dengan aborsi/abortus bukan merupakan sebuah rahasia umum dan tabu untuk diperbincangkan. Abortus adalah pengguguran kandungan seorang wanita, yang dimaksud dengan tindakan menggugurkan kandungan adalah melakukan tindakan apapun bentuk dan caranya terhadap rahim wanita yang sedang hamil yang mengakibatkan kelahiran bayi atau janin dalam kandungan wanita tersebut sebelum saatnya terjadinya kelahiran menurut sifat/waktu normal persalinan (Ummah, 2014; Wijayati, 2015).

Menurut Anshor, Nedra, \& Sururin (2002) yang dimaksud dengan penghentian kehamilan atau yang biasa disebut dengan pengguguran kandungan yang disengaja adalah penghentian kehamilan dilakukan berdasarkan gejala medis dan kontra indikasi, antara lain hipertensi, metabolik persalinan, kanker dan gangguan fisik lain yang mengancam kehidupan. Ketentuan yang mengatur tentang pengguguran kandungan, di Indonesia diatur pada Wetboek van Staatsrecht dan/atau kitab hukum pidana khususnya Pasal 299, Pasal 346 hingga Pasal 349 Bab XIX, sedangkan dalam UU Kesehatan Nomor 36 Tahun 2009 pengguguran kandungan juga diatur dalam Pasal 75 dan Pasal 76. Ada perbedaan di antara KUHP dengan UU Kesehatan dalam mengatur problematika pengguguran kandungan dan penghentian kehamilan. Wetboek van Staatsrecht atau KUHP secara tegas melarang tindakan pengguguran kandungan terhadap perempuan tanpa terkecuali dengan alasan apapun, padahal dalam UU Kesehatan mengijinkan untuk dilakukannya pengguguran kandungan atas gejala medis dan kehamilan wanita yang mengalami peristiwa pemerkosaan. Namun pengaturan mengenai pengguguran kandungan dalam UU No. 36 Tahun 2009 masih memiliki batasan-batasan untuk dapat dilakukannya pengguguran kandungan, batasan tersebut adalah pengguguran janin tidak boleh dilakukan ketika usia janin yang masih dalam kandungan berusia 6 bulan setelah hari pertama menstruasi yang terakhir.

Ketentuan yang terdapat dalam UU Kesehatan mengatur ketentuan yang mengizinkan untuk dilakukannya pengguguran kandungan, yaitu dilakukan dengan didampingi dan atas saran dari tenaga medis setelah dilakukannya analisa dan rekam medis terhadap kandungan seorang wanita apabila mengalami gejala medis yang dapat membahayakan keselamatan nyawa dari si perempuan / janin yang berada di dalam kandungannya akibat dari peristiwa pemerkosaan yang dialaminya yang diperkuat dengan bukti-bukti yang diperoleh dari lembaga yang berwenang seperti Kepolisian dan Lembaga Kesehatan yang berwenang dalam hal pengguguran kandungan (Sri, 2002). Pengguguran kandungan yang dilakukan oleh perempuan hamil yang kandungannya dideteksi mengalami indikasi medis yang dapat membahayakan nyawa perempuan tersebut atau kehamilan yang terjadi akibat mengalami peristiwa pemerkosaan, atas dasar tersebut tindakan pengguguran kandungan secara sengaja sebelum waktunya yang dilakukan oleh tenaga kesehatan dapat dibenarkan dan dilegalkan apabila memenuhi kualifikasi dan persyaratan sesuai dengan Pasal 75 ayat (2) dan Pasal 76 UU Kesehatan. Sehingga perbuatan pengguguran kandungan yang dilakukan oleh tenaga kesehatan adalah suatu pelaksanaan yang sah atau dapat dilindungi dan dibenarkan, karena telah dilakukan sesuai dengan kualifikasi dan syarat dan ketentuan yang diatur dalam pasal 75 dan 76 UU Kesehatan, agar tindakan pengguguran kandungan yang dilakukan oleh tenaga medis terhadap kandungan seorang wanita tidak tergolong sebagai sebuah tindak pidana / kejahatan (Lamintang, 2010). Dewasa ini, beberapa kasus pengguguran kandungan yang dilakukan secara terselubung/ilegal ternyata yang berperan dalam membantu pengguguran kandungan tersebut adalah tenaga kesehatan bidan, contohnya pada praktek aborsi yang terjadi di kawasan Senen, Jakarta Pusat yang dilakukan oleh dokter yang dibantu bidan (Rosalind Angel Fanggi, 2012). Dalam melaksanakan praktik aborsi ilegal, penggugur kehamilan yang dilakukan oleh dokter dibantu oleh bidan dilakukan tanpa memperhatikan syarat pertimbangan medis yang telah diatur pada Pasal 75 ayat (2) UU Kesehatan, sehingga tindakan pengguguran kandungan seorang wanita tersebut tergolong dalam perbuatan yang ilegal dan tidak dapat dibenarkan secara hukum.

Berdasarkan penjabaran permasalahan yang telah dipaparkan di awal, maka penelitian ini dirumuskan untuk mengetahui pengaturan hukum yang mengatur tentang perbuatan Abortus provocatus secara legal, serta untuk mengetahui pertanggungjawaban pidana yang diberikan terhadap bidan yang membantu menangani abortus provocatus secara ilegal. 


\section{METODE PENELITIAN}

Penelitian yang digunakan adalah penelitian hukum normatif (Hartono, 1994) yaitu penelitian dilakukan dengan menganalisa peraturan perundang-undangan yang berlaku. Mengenai sumber bahan hukum yang digunakan terbagi atas Bahan Hukum Primer adalah bahan hukum yang utama yang menjadi dasar kajian dari penelitian ini. Bahan Hukum sekunder adalah adalah bahan hukum yang digunakan untuk menunjang atau membantu dalam memberikan pemahaman-pemahaman dan gambaran-gambaran serta teori-teori hukum yang digunakan untuk mengulas dan memecahkan persoalan-persoalan yang akan di teliti di dalam penelitian penulisan skripsi. Selanjutnya Bahan Hukum Tersier adalah bahan hukum yang memberikan pedoman dan interpretasi bagi bahan hukum tingkat pertama dan kedua. Teknik pengumpulan bahan dalam penelitian menggunakan teknik studi pustaka (library research) yaitu membaca, mencatat, mengutip, meringkas, dan menelaah informasi data dari peraturan atau literatur yang terkait dengan masalah tersebut. Setelah bahan hukum telah terkumpul melalui proses studi pustaka, dalam menganalisis bahan hukum yang telah terkumpul dalam penelitian ini penulis menggunakan uraian teknis, sistematisasi, argumentasi dan interpretasi hukum berdasarkan logika deduktif dan induktif. Ditinjau sesuai kebutuhan dengan menggunakan pendekatan kualitatif. Selanjutnya setelah bahan hukum primer dan sekunder terkumpul, ini akan diolah dan dianalisis menggunakan metode penanganan bahan hukum yang sistematis (Sunggono, 2002).

\section{HASIL DAN PEMBAHASAN}

\section{Pengaturan Tentang Perbuatan Abortus Provocatus Secara Legal}

Mengacu kepada pasal 75 ayat (2) UU Kesehatan, terlihat bahwa pengguguran kandungan dan/atau penghentian kehamilan yang dilakukan secara sengaja merupakan tindakan dan/atau perbuatan legal apabila tindakan tersebut dilakukan terhadap kehamilan seorang wanita yang memiliki gejala medis yang telah diketahui sejak awal kehamilan yang dapat mengancam dan membahayakan nyawa ibu / janin yang berada dalam kandungan, serta janin yang menderita penyakit genetik serius / cacat bawaan yang tidak mungkin untuk dapat disembuhkan sehingga berpotensi menyulitkan serta mengganggu bayi tersebut untuk hidup dengan normal pada umumnya di luar kandungan, serta pengguguran kandungan legal untuk dilakukan terhadap kehamilan akibat pemerkosaan yang telah diperkuat bukti-bukti yang diperoleh dari lembaga yang berwenang seperti Kepolisian dan Lembaga Kesehatan yang berwenang dalam hal pengguguran kandungan (Sri, 2002), kemudian dipertegas mengenai legalitas tindakan pengguguran kandungan yang diatur dalam Pasal 31-37 PP Nomor 61 Tahun 2014 yang mengatur mengenai Kesehatan Reproduksi.

Adanya pengaturan yang melegalkan perbuatan pengguguran kandungan sebagai perlindungan dan kepastian hukum bagi wanita hamil yang hendak melaksanakan perbuatan pengguguran kandungan akibat dari kehamilannya mengalami gejala kedaruratan medis yang dapat mengancam nyawa nya / janin yang sedang dikandungnya mengalami cacat genetik yang tidak dimungkinkan untuk dapat diperbaiki sehingga dapat menyebabkan bayi tersebut sulit untuk menjalani kehidupan secara normal, selain itu bagi tenaga kesehatan seperti dokter dan bidan yang menangani/membantu menangani perbuatan pengguguran kandungan juga mendapat perlindungan dan kepastian hukum agar terhindar dari jerat hukum yang mengatur mengenai perbuatan pengguguran kandungan yang pelaksanaannya tidak tidak sesuai dengan ketentuan yang terdapat pada pasal 75 ayat (2) UU Kesehatan dan PP Nomor 61 Tahun 2014 yang mengatur tentang Kesehatan Reproduksi.

\section{Pertanggungjawaban Pidana terhadap Bidan yang Membantu Menangani Abortus Provocatus Secara Ilegal}

Dewasa ini, banyak ditemukan tindakan abortus provocatus dilakukan oleh kalangan dokter dan dibantu tenaga medis lainnya seperti bidan yang dilakukan secara ilegal dan tidak berdasarkan pada pasal 75 ayat (2) dan Pasal 76 UU Kesehatan, Contohnya pada kasus praktik pengguguran kandungan ilegal yang terjadi di daerah Senen, Jakarta Pusat, yang berhasil di ungkap oleh Polda Metro Jaya pada pada hari selasa tanggal 14 Februari tahun 2020, pada saat melakukan penggerebekan polisi menangkap dan menetapkan tiga orang tersangka yaitu seorang dokter, yang dibantu dua orang bidan serta seorang pemegang administrasi dan keuangan. Berdasarkan hasil penyelidikan sementara, polisi menduga ketiga tersangka tidak bekerja sendiri, selama beroperasi sejak tahun 2018, klinik ini telah membunuh 903 janin. Sebelum membahas mengenai sanksi pertanggungjawaban pidana yang 
diterima oleh bidan yang membantu dokter dalam melakukan perbuatan pengguguran kandungan terhadap kehamilan seorang wanita yang dilakukan tidak sesuai dengan ketentuan pada Pasal 75 ayat (2) dan Pasal 76 UU Kesehatan, terlebih dahulu perlu membahas tentang pertanggungjawaban pidana dokter, apakah dokter yang melakukan pengguguran kandungan yang tidak memperhatikan ketentuan yang terdapat pada Pasal 75 ayat (2) dan Pasal 76 UU Kesehatan dapat dikenakan sanksi pertanggungjawaban pidana berdasarkan ketentuan Pasal 349 KUHP atau berdasarkan ketentuan dalam Pasal 194 UU Kesehatan. Sehingga dalam memecahkan masalah norma konflik ini diberlakukan asas preferensi Lex Specialis Derogat Legi Generalis yaitu ketentuan atau peraturan yang sifatnya umum akan dikesampingkan oleh ketentuan yang bersifat lebih khusus, yakni dalam hal ini UU Kesehatan No. 36 Tahun 2009 lebih diutamakan daripada Wetboek van Staatsrecht (KUHP) yang sifatnya umum.

Mengenai sanksi pertanggungjawaban pidana yang terhadap dokter yang melakukan tindakan pengguguran kandungan atau abortus provocatus yang tidak memperhatikan ketentuan yang terdapat pada Pasal 75 ayat (2) dan Pasal 76 UU No. 36 Tahun 2009, dapat dikenakan pertanggungjawaban pidana berdasarkan ketentuan Pasal 194 UU No. 36 tahun 2009, dengan sanksi pidana penjara, yaitu paling lama 10 (sepuluh) tahun dan didenda terbanyak, sebanyak 1 miliar rupiah apabila melakukan tindakan pengguguran kandungan dengan tidak mematuhi ketentuan yang terdapat pada pasal 75 ayat (2) dan Pasal 76 UU Kesehatan No. 36 Tahun 2009. Membahas mengenai pertanggungjawaban pidana bagi bidan yang ikut membantu dokter dalam penanganan pengguguran kandungan yang dilakukan secara ilegal dan/atau yang bertentangan dengan pengaturan yang terdapat pada Pasal 75 ayat (2) dan Pasal 76 UU Nomor 36 Tahun 2009 tentang Kesehatan, dalam cakupan hukum pidana, bidan yang ikut membantu dokter dalam menangani tindakan pengguguran kandungan yang dilakukan secara ilegal dikategorikan sebagai Medepleger (ikut serta) dan / atau ikut melakukan sesuatu yaitu tindak pidana. Sehingga untuk membuktikan bahwa tenaga kesehatan bidan berperan sebagai medepleger dalam tindakan pengguguran kandungan yang dilakukan oleh dokter secara tidak sah, terdapat syarat-syarat dan unsur-unsur yang harus dipenuhi, yaitu:

1) Ketika melakukan suatu tindak pidana terdapat unsur kerjasama yang dilakukan secara sadar oleh para pelaku

2) Kerjasama tersebut bertujuan melanggar hukum

3) Pelaksanaan suatu tindak pidana tersebut dilakukan bersama-sama secara fisik hingga perbuatan tersebut diselesaikan dengan baik.

Medepleger (ikut serta) diatur dalam Pasal 55 ayat (1) ke-1 KUHP, sehingga pertanggungjawaban pidana kepada bidan yang tergolong sebagai medepleger (ikut serta) karena ikut membantu terjadinya tindak pidana yaitu membantu dokter dalam penanganan penggugurankandungan yang dilakukan secara tidak sah yang tidak berdasarkan ketentuan Pasal 75 ayat (2) dan Pasal 76 UU No. 36 Tahun 2009, dapat dikenakan pertanggungjawaban pidana berdasarkan pada Pasal 194 UU Kesehatan No. 36 tahun 2009 Jo Pasal 55 ayat (1) ke-1 KUHP. Mengacu pada Pasal 55 ayat (1) ke-1 dan Pasal 57 hukum pidana tentang pertanggungjawaban pidana bagi bidan yang ikut membantu dokter dalam menangani pengguguran kehamilan secara tidak sah / ilegal, terlihat bahwa pertanggungjawaban pidana yang dijatuhkan sanksinya berkurang sepertiga dari hukuman yang diterima dokter yang dikenakan sanksi pidana berdasarkan ketentuan Pasal 194 UU Kesehatan, karena bidan tergolong sebagai turut serta membantu dalam tindakan pengguguran kehamilan yang dilakukan oleh dokter secara ilegal. Selanjutnya, jika majelis hakim memutuskan untuk menjatuhkan hukuman mati atau pidana penjara seumur hidup bagi dokter dalam kasus aborsi ilegal, bidan yang turut membantu dokter tersebut diancam sanksi pidana penjara paling lama, selama 15 tahun.

Pertanggungjawaban pidana kepada bidan yang turut serta membantu dokter dalam melakukan tindakan pengguguran kandungan yang dilakukan dengan ilegal, dapat dilihat bahwa pertanggungjawaban pidana yang diterima oleh bidan sanksinya berbeda dengan pertanggungjawaban yang diterima oleh dokter sebagai pelaku utama dalam menangani tindakan pengguguran kandungan yang dilakukan dengan ilegal, karena kedudukan bidan tersebut sebagai turut serta melakukan pembantuan (medepleger). Berdasarkan penjelasan diatas, dapat diketahui bahwa bidan yang turut serta membantu dokter dalam menangani tindakan pengguguran kandungan yang dilakukan dengan ilegal dikenakan sanksi pertanggungjawaban pidana berdasarkan kitab hukum pidana, sedangkan dokter 
yang merupakan pelaku utama dalam menangani tindakan pengguguran kandungan dikenakan sanksi pertanggungjawaban pidana berdasarkan pada UU Kesehatan.

\section{SIMPULAN DAN SARAN \\ 1. Simpulan}

Berdasarkan hasil penelitian di atas, dapat disimpulkan bahwa pengaturan hukum mengenai tindakan aborsi provocatus secara legal diatur pada Pasal 75 ayat (2) UU Kesehatan, yang menyatakan bahwa larangan melakukan pengguguran dapat dicabut apabila dilakukan pada wanita hamil yang kandungannya mengalami gejala keadaan darurat medis yang membahayakan nyawanya / janin yang sedang dikandungnya mengidap penyakit-penyakit genetik atau cacat bawaan yang tidak memungkinkan untuk dapat disembuhkan sehingga berpotensi menyulitkan bayi untuk melangsungkan hidup secara normal. Selain itu pengguguran kandungan legal dilakukan pada kehamilan wanita akibat korban pemerkosaan. Legalitas pengguguran kehamilan seorang wanita kemudian diperkuat dan dikukuhkan dalam PP No. 61 Tahun 2014. Adapun pertanggungjawaban secara pidana bagi bidan yang ikut serta membantu dokter dalam menangani perbuatan pengguguran kandungan seorang wanita secara ilegal dapat dipidana dengan pidana penjara berdasarkan pada ketentuan Pasal 194 UU Kesehatan jo. Pasal 55 ayat (1) 1 KUHP, dimana sanksi pidana yang diterima berdasarkan Pasal 57 KUHP berkurang sepertiga dari hukuman yang diterima oleh dokter sebagai pelaku utama dalam menangani tindakan pengguguran kandungan yang dilakukan secara melawan hukum, jika dokter dijatuhi hukuman mati atau pidana penjara seumur hidup, maka bidan yang ikut membantu, diancam dengan hukuman pidana penjara paling lama, selama 15 tahun.

\section{Saran}

Adapun saran yang hendak disampaikan yakni, diharapkan agar pemerintah memperjelas dan mempertegas kembali, apa yang dimaksud dari indikasi kedaruratan medis yang dapat mengancam nyawa ibu sebagai salah satu syarat untuk dapat dikecualikannya larangan tindakan pengguguran kandungan sebagaimana dimaksud dalam pasal 75 ayat (2) UU Kesehatan, agar indikasi kedaruratan medis yang dapat mengancam nyawa ibu sebagaimana dimaksud di dalam pasal 75 ayat (1) UU Kesehatan tidak dimanfaatkan dan dijadikan celah oleh oknum tertentu untuk melakukan tindakan abortus provocatus yang tidak sesuai dengan Pasal 75 ayat (2) UU Kesehatan. Selanjutnya, diharapkan agar pemerintah dalam menyusun rancangan Wetboek van Staatrecht (KUHP) yang baru, agar mengatur perbuatan pengguguran kandungan dengan jelas dan tegas, karena perbuatan pengguguran kandungan dalam Wetboek van Staatrecht (KUHP) yang berlaku saat ini kurang jelas pemaknaannya, agar sejalan dengan aturan hukum lainnya yang mengatur tentang perbuatan pengguguran kandungan, agar tidak terjadi norma konflik dalam pemaknaan dari perbuatan pengguguran kandungan.

\section{DAFTAR PUSTAKA}

Anshor, M. U., Nedra, W., \& Sururin. (2002). Aborsi dalam Perspektif FIQH Kontemporer. Jakarta: Fakultas Kedokteran Universitas Indonesia.

Hamenda, V. L. (2013). Tinjauan Hak Asasi Manusia terhadap Penerapan Hukuman Mati di Indonesia. Lex Crimen, II(1), 113-119.

Hartono, S. (1994). Penelitian Hukum di Indonesia pada Akhir Abad ke-20. Bandung: Alumni.

Lamintang, P. A. F. (2010). Delik-delik khusus : Kejahatan terhadap Nyawa, Tubuh \& Kesehatan. Jakarta: Sinar Grafika.

Rosalind Angel Fanggi. (2012). Kebijakan Kriminalisasi Pengguguran Kandungan dalam Pembaruan Hukum Pidana Indonesia. Law Reform, 7(2), 190-213.

Sri, S. (2002). Masalah Abortus Provocatus di Indonesia dan Hubungannya dengan Keluarga Berencana Ditinjau dari Kitab Undang-Undang Hukum Pidana. Jakarta: Sinar Grafika.

Sunggono, B. (2002). Metodologi Penelitian Hukum (Cet. Keemp). Jakarta: PT Raja Grafindo Persada. Ummah, S. choirol. (2014). Tindakan Aborsi di Indonesia Menurut Hukum Islam. Humanika, 14(1), 1-14.

Wijayati, M. (2015). Aborsi Akibat Kehamilan yang Tak Diinginkan (KTD) : Kontestasi Antara Pro-Live dan Pro-Choice. ANALISIS: Jurnal Studi Keislaman, 15(1), 43-62. 